\title{
Grammar and Composition
}

\author{
Jong-Bok Kim \\ School of English \\ Kyung Hee Univ. \\ Tel: 02-961-0892 \\ Office: Faculty Bld. 305 \\ jongbok@khu.ac.kr \\ http://web.khu.ac.kr/ jongbok \\ 2007, Spring Semester
}

\section{Course Descriptions:}

The goals of this course is to

- $\quad$ help students to explore English grammar through a unique 'discovery' approach that encompasses both critical thinking and text analysis

- study English grammar from a theoretically/descriptively informed perspective ? seek the right balance in our English grammar teaching between theory and practice

- $\quad$ help (prospective) teachers to be able to apply this knowledge in various contexts.

This course is ideal and useful for those interested in English education/language arts, English as a second language, and linguistics.

The class will cover the basic grammar rules and major English constructions. After each chapter, students will have a writing assignment that tests the grammar rules covered in the chapter. Students who successfully finish this course will be able to apply their understanding of grammar structure to the EFL classroom. As usual, this class consists of two class hours as a unit. Students are required to read the main textbooks thoroughly and do exercises as homework.

\section{Main Textbook:}

- Huddleston R. and G. Pullum. 2005. A student's introduction to English Grammar. Cambridge University Press.

- Williams, Joseph M. 2006. Style: The basics of clarity and grace. Longman.

\section{References:}


- Huddleston, Rodney, and Geoffrey K. Pullman. 2002. The Cambridge Grammar of the English Language. Cambridge University Press.

- Quirk, Randoph, Sidney Greenbaum, Geoffrey Leech, and Jan Svartvik. 1985. A Comprehensive Grammar of the English Language. London and New York: Longman.

- $\quad$ ABC of common grammatical errors, Nigel D Turton, Macmillan Publishers, 1995.

\section{Course Schedule:}

\begin{tabular}{|c|c|c|c|}
\hline Week & Dates & Chapters & Homework \\
\hline 1 & Mar 6, 8 & Chap 1,2 Intro. and Rapid overview & \\
\hline 2 & Mar 13,15 & Chap 3 verbs & Chap 1/2 Ex. W: 1 and 2 \\
\hline 3 & Mar 20, 22 & Chap 4 clauses & Chap 3 Ex. W: 3 \\
\hline 4 & Mar 27, 29 & Chap 5 nouns & Chap 4 Ex. W: 4 \\
\hline 5 & Apr 3,5 & Chap 6 adjectives and adverbs & Chap 5 Ex. W: 5 \\
\hline 6 & Apr 10,12 & Chap 7 prepositions & Chap 6 Ex. \\
\hline 7 & Apr 17,19 & Chap 8 negation & Chap $7 / 8$ Ex. \\
\hline 8 & Apr 24,26 & Mid term & \\
\hline 9 & May 1, 3 & Chap 9 clause type & Chap 9 ex. W: 6 \\
\hline 10 & May 8,10 & Chap 10 subordination & Chap 10 ex. W: 7 \\
\hline 11 & May 15,17 & Chap 11 relative clause & Chap 11 Ex. W: 8 \\
\hline 12 & May $22,24(\mathrm{~B})$ & Chap 12 grade and comparison & Chap 12 Ex. W: 9 \\
\hline 13 & May 29,31 & Chap 13 nonfinite clauses & Chap 13 Ex. W: 10 \\
\hline 14 & June 5,7 & Chap 14 coordination & Chap 14 Ex. \\
\hline 15 & June 12,14 & Chap 15 information packaging & chap 15 ex. \\
\hline 16 & June 19,21 & Final & \\
\hline
\end{tabular}

Note: The class schedule is subject to change.

Evaluations: $\quad$ Mid Term $35 \%$ and Final: $35 \%$, Class attendance and participation in class activities: 10\%, Homework Assignments: $20 \%$

\section{Requirements and Notes:}

- All the homework need to be handwritten and must be submitted on the designated date. No late submission is possible. (Please make no front cover for the homework to save paper!)

- Students are strongly encouraged not to miss any class. You are allowed to miss one class. Missing the second one needs to have an email notification to me. If missing more than 3 classes, no grades will be given.

- $\quad$ Email is the most accessible way to reach me. Feel free to write to me for questions.

- Asking questions either in the class or through email are strongly encouraged. Remember every question has its own value and more questions mean a better grade. 